\title{
Neoadjuvant chemotherapy for locally advanced stage (IB2-IIA2-IIB) cervical carcinoma: Experience of a tertiary center and comprehensive review of the literature
}

\author{
Lokal olarak ileri evre (IB2-IIA2-IIB) servikal karsinom \\ için neoadjuvan kemoterapi: Tersiyer merkez deneyimi ve \\ literatürün kapsamlı incelemesi
}

\author{
(1) Caner Çakır, (1) Fatih Kılıç, (1) Rıza Dur, (1) Dilek Yüksel, (1) Mehmet Ünsal, (1) Vakkas Korkmaz, \\ (1) Çiğdem Kılıç, (1) Günsu Kimyon Cömert, (1) Nurettin Boran, (1) Osman Türkmen, (1) Sevgi Koç, (1) Taner Turan
}

Etlik Zübeyde Hantm Women's Health Training and Research Hospital, Clinic of Obstetrics and Gynecology, Ankara, Turkey

\begin{abstract}
Objective: This study aimed to evaluate neoadjuvant chemotherapy (NACT) for locally advanced stage cervical carcinoma.

Materials and Methods: Data of 43 patients with locally advanced cervical carcinoma who had NACT were reviewed. NACT protocols implemented included cisplatin/5-fluorauracil, cisplatin/UFT, and carboplatin/paclitaxel. After NACT, the patients were re-examined, and patients who had a tumor size $\leq 40 \mathrm{~mm}$ underwent Piver-Rutledge type III radical hysterectomy, while other patients received radiotherapy. Following NACT, clinical responses were assessed according to the criteria of the World Health Organization.

Results: The mean age of the patients was 49.4 years, and the median follow-up duration was 48 (range, 5-228) months. The median tumor sizes were 50 and $30 \mathrm{~mm}$ before and after NACT, respectively. Complete clinical response was observed in 4 (9.3\%) patients, partial clinical response in 8 (18.6\%), and pathologic complete response in 3 (6.9\%). Stable disease was noted in 30 (69.9\%) patients and progression in 1 (2.3\%) patient. After NACT, 31 patients have undergone radical surgical procedures. The 5-year disease-free survival rate was $72 \%$, and the 5-year disease-specific survival rate was $91 \%$. Age, International Federation of Gynaecology and Obstetrics 2009 stage, histopathologic type, NACT protocol, rate of decrease in tumor size after NACT, clinical response, number of courses, tumor size before NACT, tumor size after NACT, and lymph node metastasis were not associated with disease-free survival. Conclusion: Following NACT, a significant reduction in tumor dimension was observed, and the probability of radical surgery is increased. However, clinical response was not predictive of survival.

Keywords: Cervical carcinoma, locally advanced stage, neoadjuvant chemotherapy, survival

$\ddot{\mathrm{O} z}$

Amaç: Bu çalışmada neoadjuvan kemoterapinin (NACT) etkinliği değerlendirilmiştir. NACT, lokal olarak ilerlemiş servikal karsinomda başlangıç tedavisi için yöntemlerden biridir.

Gereç ve Yöntemler: Lokal olarak ilerlemiş servikal karsinomlu, NACT olan 43 hastanın verileri gözden geçirildi. NACT protokolleri sisplatin/5-fluorourasil, sisplatin/UFT ve karboplatin/paklitaksel idi. NACT sonrası hastalar tekrar muayene edildi ve tümör boyutu $40 \mathrm{~mm}$ ve altı olan hastalar ameliyat edildi (Piver-Rutledge tip III radikal histerektomi) ve diğer hastalara radyoterapi verildi. NACT klinik yanıtı, Dünya Sağllk Örgütü kriterlerine göre değerlendirildi. Bulgular: Hastaların ortalama yaşı 49,4 yıl ve ortanca takip süresi 48 (aralık, 5-228) aydı. Ortalama tümör boyutu NACT'den önce 50 mm ve NACT'den sonra 30 mm idi. Yanıt oranları așağıdaki gibidir; dört hastada $(\% 9,3)$ tam klinik yanıt, sekiz hastada $(\% 18,6)$ kısmi klinik yanıt ve üc hastada $(\% 6,9)$ patolojik tam yanıt. Otuz hastada $(\% 69,9)$ stabil hastalık ve bir hastada $(\% 2,3)$ progresyon görüldü. NACT'den sonra 31 hasta radikal cerrahi prosedür geçirdi. Beş yıllık hastalıksız sağkalım \%72,5 yıllık hastalı̆̆a özgü sağkalım \%91 idi. Yaş, Uluslararası Jinekoloji ve Obstetrik Federasyonu 2009 evresi,
\end{abstract}

PRECIS: This study evaluated the outcomes of neoadjuvant chemotherapy in cervical carcinoma.

Address for Correspondence/Yazışma Adresi: Caner Çakır MD

Etlik Zübeyde Hanım Women's Health Training and Research Hospital, Clinic of Obstetrics and Gynecology, Ankara, Turkey

Phone: +90 5305608488 E-mail: caner4084@gmail.com ORCID ID: orcid.org/0000-0003-2559-9104

Received/Geliș Tarihi: 11.03.2021 Accepted/Kabul Tarihi: 14.06.2021

${ }^{\oplus}$ Copyright 2021 by Turkish Society of Obstetrics and Gynecology

Turkish Journal of Obstetrics and Gynecology published by Galenos Publishing House. 
histopatolojik tip, NACT protokolü, NACT sonrası tümör boyutundaki azalma oranı, klinik yanıt, kurs sayısı, NACT öncesi tümör boyutu, NACT sonrası tümör boyutu ve lenf nodu metastazı hastalıksız sağkalım ile ilişkili değildi.

Sonuç: NACT sonrası tümör boyutunda önemli bir azalma oldu ve radikal cerrahi olasılığı arttı. Ancak klinik yanıt, sağkalımı tahmin etmedi. Anahtar Kelimeler: Serviks kanseri, lokal ileri evre, neoadjuvant kemoterapi, sağkalım

\section{Introduction}

Cervical carcinoma (CC) is the fourth most common cancer in women worldwide, and it is the fourth leading cause of cancerrelated deaths ${ }^{(1)}$. The type of treatment type is based on the disease stage. Surgery, radiotherapy (RT), and chemotherapy (CT) have been suggested as standard treatment approaches ${ }^{(2)}$. The effectiveness of radical hysterectomy (RH) and RT in earlystage CC is comparable ${ }^{(3)}$. Owing to the preservation of ovarian activity, having lesser sexual dysfunction in surgery than in RT, and leaving RT as an alternative treatment for recurrence, surgery is currently the preferred method of treatment CC. However, after RH, the need for RT increases. Landoni et al. ${ }^{(4)}$ reported that $84 \%$ of patients with stage IB-IIA disease received postoperative RT.

Concurrent chemoradiation used to enhance the effect of RT on the treatment of recurrence and locally advanced CC improves the response rate and survival of the patients ${ }^{(5)}$. This treatment modality not only controlled the course of a localized tumor but also decreased distant metastasis; thus, neoadjuvant chemotherapy (NACT) becomes a current issue. The main objectives of NACT are to eliminate micrometastasis, make the tumor smaller enough for surgical removal, and increase the survival of patients following the RF or RT. However, RT following NACT (sequential RT) had no effect on survival ${ }^{(6,7)}$ and even worsened $i^{(8,9)}$. These negative results are explained by the cross-resistance between the two treatment modalities and intracellular alterations ${ }^{(10)}$. By contrast, the cross-resistance problem does not exist in $\mathrm{RH}$ and the residual tumor is removed. Therefore, RF following the NACT is expected to increase patient survival. In a meta-analysis of 21 phase III trials, NACT followed by RH improved overall survival (OS) by $14 \%$ in comparison with RT alone ${ }^{(11)}$. However, in a study of the gynecologic oncology group (GOG), compared with NACT followed by RH, RH alone did not show any improvement ${ }^{(12)}$. The value of NACT in the treatment of CC is not appropriately defined until now; especially, in early-stage CC, uncertainty is much more common. Thus, this study aimed to evaluate the effect of NACT on the outcomes of patients with locally advanced CC (stage IB2, IIA2, and IIB).

\section{Materials and Methods}

Medical records of patients with stage IB2, IIA2, or IIB CC between 1998 and 2020 were reviewed retrospectively. This study included 43 patients who received NACT. These patients were staged according to the International Federation of Gynecology and Obstetrics (FIGO 2009) staging system. In all patients, diseases were staged using upper abdominal tomography, pelvic magnetic resonance imaging (intravenous pyelography as needed), and gynecologic examination under general anesthesia. Histopathological evaluation was carried out according to the 2014 World Health Organization (WHO) criteria $^{(13)}$. This study was approved by the local ethical committee (file no. 90057706-799/08; 05.06.2020).

Cisplatin/5-fluorouracil (5-FU) (CF), cisplatin/UFT ${ }^{\mathrm{TM}}$ (CU), and carboplatin/paclitaxel (CbP) combinations were applied as NACT protocols. The CF protocol started with cisplatin at a dose of $75 \mathrm{mg} / \mathrm{m}^{2}$, given as an infusion within $1 \mathrm{~h}$, followed by 5 -FU at a dose of $500 \mathrm{mg} / \mathrm{m}^{2}$ given within $6 \mathrm{~h}$. The 5 -FU dose was repeated at days 2-5 of the protocol. CT was given at 28 days intervals. The CU protocol was started with cisplatin at a dose of $75 \mathrm{mg} / \mathrm{m}^{2}$, given as an infusion within $1 \mathrm{~h}$. UFT ${ }^{\mathrm{TM}}$ [urasil (224 mg)-tegafur (100 mg) capsule, Bristol-Myers Squibb, NY, USA] was started at the same day as one capsule administered orally for 14 days. CT was given at 21 days intervals. The CbP protocol started with paclitaxel at a dose of $175 \mathrm{mg} / \mathrm{m}^{2}$, given as an infusion within $3 \mathrm{~h}$, followed by carboplatin dose calculated by using an area under curve of 6 (maximum dose of $750 \mathrm{mg}$ ) given within CT, the following criteria were supplied: (i) performance status $\leq 2$ according to the Eastern Cooperative Oncology Group standards, (ii) adequate bone marrow function (leukocytes $\geq 3.000 / \mathrm{mL}$, neutrophils $\geq 1.500 / \mathrm{mL}$, platelets $\geq 100.000 / \mathrm{mL}$, and hemoglobin $\geq 10 \mathrm{mg} / \mathrm{dL}$ ), (iii) adequate hepatic function (total bilirubin, alanine aminotransferase, and aspartate aminotransferase levels were below twice of the upper limits), and (iv) adequate renal function (glomerular filtration rate $>60 \mathrm{~mL} / \mathrm{min}$ ). Patients were evaluated for CT toxicity and adjustment of the next dose based on the complete blood counts and biochemical tests at every 10 days. Toxicity was assessed according to the WHO criteria ${ }^{(14)}$.

Patients were re-examined under general anesthesia after two or three cycles of NACT. Patients who had tumors $\leq 40 \mathrm{~mm}$ underwent to Piver-Rutledge type III hysterectomy, while other patients received RT. Adjuvant treatment decisions for all patients were made by a gynecologic oncology council after RH. Patients with high-risk status received postoperative RT. Up until 2001, the criterion for postoperative adjuvant RT was the presence of at least one of the major risk factors (i.e., positive lymph nodes, parametrial involvement, presence of a tumor within the surgical margins, and tumor size $\geq 4 \mathrm{~cm}$ ) or two of the minor risk factors (i.e., lymphovascular space invasion, stromal invasion of $\geq 1 / 2$, tumor size $2-4 \mathrm{~cm}$, and $\geq 3$ lymph nodes with microscopic metastasis). After 2001, only patients with positive lymph nodes and/or parametrial involvement and/or a tumor within the surgical margins received adjuvant RT. RT was administered alone or in combination with CT (concurrent chemoradiation). 
Following the $\mathrm{CT}$, clinical responses were assessed according to the WHO criteria ${ }^{(14)}$ : complete clinical response (CCR), absence of gross tumor; partial clinical response (PCR), $>50 \%$ decrease in tumor size; stable disease (SD), $<50 \%$ decrease or $<25 \%$ increase in tumor size; progressive disease (PD), $>25 \%$ increase in tumor size or new tumor foci were found. The absence of tumor in the pathology specimen (RH, ovaries, and lymph nodes) was defined as pathologic complete response (Pat CR). Patients were followed by a pelvic examination, vaginal smear, abdominal ultrasonography, whole blood count, and blood biochemistry tests in the first 2 years after treatment in every 3 months, every 6 months up to the fifth year, and then once a year. Chest X-ray imaging was requested annually or when clinically suspicious recurrence was detected. Advanced imaging techniques (computed tomography, magnetic resonance imaging, or positron emission tomographycomputed tomography) were performed when necessary. If recurrence was detected during follow-up, the time and site of recurrence were recorded. Deaths were also recorded.

The time from the first dose of NACT to any cause of death because of disease or last follow-up visit was defined as OS. The time from the first dose of NACT to death because of the disease or last follow-up visit was defined as disease-specific survival (DSS). Disease-free survival (DFS) was defined as the period from the first dose of NACT to confirmed recurrence or refractory disease with clinical examination and/or radiological imaging or the period from the initial surgery to the last followup visit in those who did not develop refractory/recurrence disease.

\section{Statistical Analysis}

SPSS 20.0 (SPSS Inc., Chicago, IL) was used for data review and statistical analysis. Descriptive statistics were expressed as mean \pm standard deviation and median (minimum-maximum) for continuous variables and $\mathrm{n}(\%)$ for categorical variables. The defining effect of surgical-pathologic factors on clinical response was assessed using the chi-square test. The KaplanMeier method was used to evaluate survival results. Survival curves were compared in the log-rank test. Significance was defined as $\mathrm{p}<0.05$.

\section{Results}

The mean age of the patients was 49.4 48.67 (range, 33-70) years. According to the FIGO 2009 staging system, 28 (65.1\%) patients had stage $\mathrm{IB}_{2}$ disease, 11 (25.6\%) had stage IIA2 disease, and 4 (9.3\%) had stage IIB disease. Histopathologic diagnosis was squamous cell carcinoma in 39 (90.7\%) patients. The median tumor size was $50 \mathrm{~mm}$ (range, $30-70 \mathrm{~mm}$ ) before NACT and $30 \mathrm{~mm}$ (range, 0-70 $\mathrm{mm}$ ) after NACT. In one patient, the tumor size was $<40 \mathrm{~mm}$ before NACT, although this patient had stage IIB disease. As a NACT regimen, 36 (83.7\%) patients received $\mathrm{CF}, 3$ (7\%) received $\mathrm{CbP}$, and 4 (9.3\%) received CU.
Moreover, 27 (62.8\%) patients received three cycles of CT and $16(37.2 \%)$ received two cycles (Table 1$)$.

The control treatment after NACT showed that the mean tumor size decreased to $32.4 \pm 15.26 \mathrm{~mm}$. Moreover, 4 (9.3\%) patients obtained CCR. The rate of decrease in tumor size was $>25 \%$ in $30(69.8 \%)$ patients and $>50 \%$ in $12(27.9 \%)$ patients. The decrease in tumor size was $<25 \%$ in six patients, but in $7(16.3 \%)$ patients, there was no change in the tumor size. Accordingly, the calculated overall clinical response (OCR) rate was $27.9 \%$ (CCR, 9.3\%, $n=4$; PCR, $18.6 \%, n=8$ ). The SD rate was $69.9 \%$ $(\mathrm{n}=30)$, whereas the PD rate was $2.3 \%(\mathrm{n}=1)($ Table 1$)$.

After NACT use, a surgical approach was feasible in 31 (72.1\%) patients. This rate was $69.4 \%$ in patients who received CF and $66.7 \%$ in patients who received CbP. Four of the patients who received CU became operable. Finally, after NACT, 31 patients underwent surgery, and Piver-Rutledge type III RH + bilateral salpingo-oophorectomy + para-aortic-bilateral pelvic lymphadenectomy was performed. Moreover 5 (11.7\%) of the remaining 12 patients received RT alone or concurrent chemoradiation, and the other 7 (16.3\%) patients received concurrent chemoradiation after extraperitoneal/transperitoneal lymph node dissection (Table 1).

The tumor size was $<4 \mathrm{~cm}$ during clinical examination in all patients who underwent surgery. However, in the postoperative pathological evaluation, the tumor size ranged from 4 to $6 \mathrm{~cm}$ in eight patients. After radical surgery of these 31 patients, $6(19.4 \%)$ were found to have parametrial involvement and 1 (3.2\%) had surgical border invasion. Lymph node metastasis was evaluated in 38 patients (31 patients underwent RH + lymphadenectomy and seven patients underwent extraperitoneal/transperitoneal lymphadenectomy + RT). Therefore, lymph node metastasis was detected in 17 (44.7\%) of these 38 patients. Moreover, 3 of 7 patients who underwent extraperitoneal/transperitoneal lymph node dissection were found to have lymph node metastasis. In the assessment after NACT, three of the four patients who had no tumor in the cervix were also tumor negative after the pathological examination. However, in one patient, although no tumor was seen in the cervix, lymph node metastasis was detected. Consequently, the Pat CR rate was 6.9\% (3/43). In addition, 24 (77.4\%) of the 31 patients received concurrent chemoradiation after radical surgery. As a result, 36 of the 43 patients received RT (Table 2).

The factors determining clinical response to NACT were investigated. We compared 31 patients who had no clinical response (SD + PD) following NACT with 12 patients who had clinical response (CCR + PCR) following NACT. Age, FIGO 2009 stage, tumor size before NACT, NACT combination, number of NACT cycles, and histopathologic type were found to be not predictive of clinical response $(\mathrm{p}>0.05)$ (Table 3$)$.

The median duration of follow-up in the entire cohort was 48 (range, 5-228) months. During follow-up, 11 patients had recurrence and six patients died. Three patients died of the disease during the study period. The 5-year DFS rate was $72 \%$, 
Table 1. Characteristics of the patients $(n=43)$

Characteristics

Mean \pm SD Median (range)

Age (years)

$49.4 \pm 8.67 \quad 48(33-70)$

Tumor size before NACT (mm)

$54.2 \pm 9.81 \quad 50(30-70)$

Tumor size after NACT (mm)

$32.4 \pm 15.26 \quad 30(0-70)$

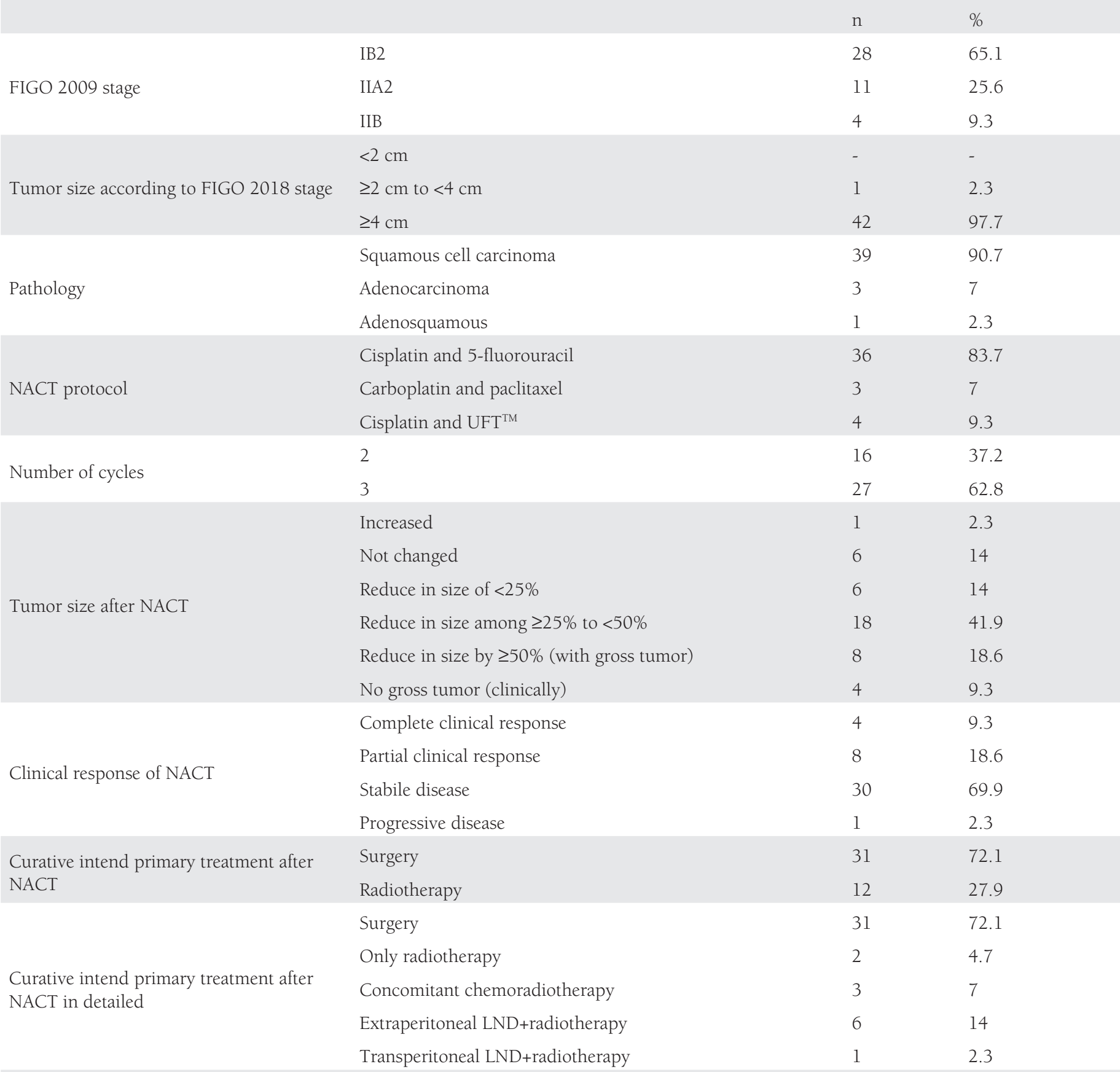

SD: Standard deviation, NACT: Neoadjuvant chemotherapy, LND: Lymphadenectomy, FIGO: Federation of Gynecology and Obstetrics

the 5-year DSS rate was $91 \%$, and the 5-year OS rate was $87 \%$ in the study group.

The effects of the clinical and pathological parameters on DFS were evaluated. Age, FIGO 2009 stage, histopathologic type, NACT protocol, treatment after NACT, rate of decrease in tumor size after NACT, clinical response (Figure 1), number of courses, tumor size before NACT, tumor size after NACT, and lymph node metastasis were not associated with DFS (Table 4). Table 5 and 6 represent the clinical response and survival rates of relevant studies investigating the efficacy of NACT in early- 
Table 2. Surgical and pathologic characteristics of patients who underwent surgery ( $\mathrm{n}=31$ patients)

\section{Characteristics}

Age (year)

Tumor size before NACT (mm)

Pathological tumor size after NACT (mm)

Number of removed lymph node ${ }^{1}$

Number of metastatic lymph node ${ }^{1}$

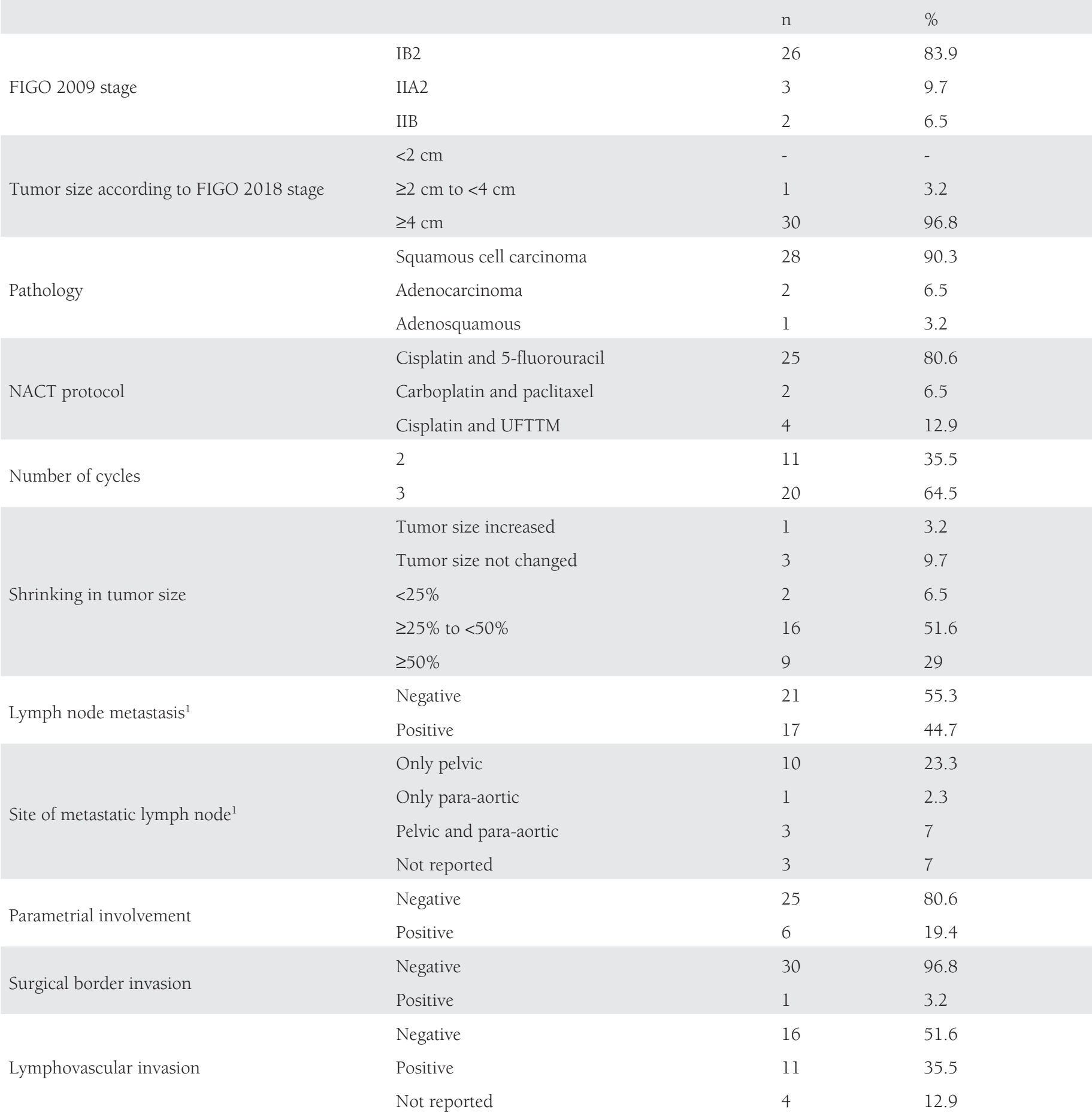

Mean \pm SD Median (range)

$48.7 \pm 7.28 \quad 48(33-66)$

$55.5 \pm 9.95 \quad 50(30-70)$

$31 \pm 16.50 \quad 30(0-60)$

$55.1 \pm 27.49 \quad 51(11-160)$

$4 \pm 3.98 \quad 2.5(1-15)$




\begin{tabular}{|c|c|c|c|}
\hline \multirow{3}{*}{ Adnexal metastasis } & Negative & 25 & 80.6 \\
\hline & Positive & 1 & 3.2 \\
\hline & Not reported & 5 & 16.1 \\
\hline \multirow{3}{*}{ Depth of the stromal invasion } & $\leq 1 / 2$ & 12 & 38.7 \\
\hline & $>1 / 2$ & 16 & 51.6 \\
\hline & Not reported & 3 & 9.7 \\
\hline \multirow{3}{*}{ Endometrial/uterine invasion } & Negative & 24 & 77.4 \\
\hline & Positive & 4 & 12.9 \\
\hline & Not reported & 3 & 9.7 \\
\hline \multirow{2}{*}{ Adjuvant radiotherapy } & Not received & 7 & 22.6 \\
\hline & Received & 24 & 77.4 \\
\hline \multirow{3}{*}{ Type of adjuvant radiotherapy } & Only radiotherapy & 2 & 6.8 \\
\hline & Concomitant chemoradiotherapy & 19 & 61.3 \\
\hline & Not reported & 3 & 9.7 \\
\hline
\end{tabular}

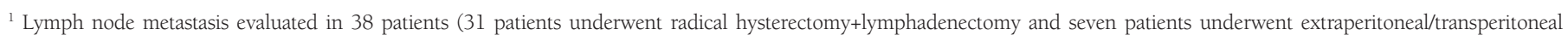
lymphadenectomy+radiotherapy), SD: Standard deviation, NACT: Neoadjuvant chemotherapy, FIGO: Federation of Gynecology and Obstetrics

Table 3. Factors predicting clinical response

\begin{tabular}{|c|c|c|c|c|}
\hline \multicolumn{2}{|l|}{ Factors } & $\begin{array}{l}\mathrm{SD}+\mathrm{PD} \\
\mathrm{n}(\%)\end{array}$ & $\begin{array}{l}\text { CCR+PCR } \\
\text { n (\%) }\end{array}$ & $\mathrm{p}$ \\
\hline \multirow{2}{*}{$\mathrm{Age}^{1}$} & $\leq 48$ years & $16(72.2)$ & $6(27.3)$ & \multirow{2}{*}{0.845} \\
\hline & $>48$ years & $14(70)$ & $6(30)$ & \\
\hline \multirow{2}{*}{ FIGO 2009 stage } & I & $18(64.3)$ & $10(35.7)$ & \multirow{2}{*}{0.119} \\
\hline & II & $13(86.7)$ & $2(13.3)$ & \\
\hline \multirow{2}{*}{$\begin{array}{l}\text { Tumor size before } \\
\text { NACT }^{1}\end{array}$} & $\leq 50 \mathrm{~mm}$ & $19(79.2)$ & $5(20.8)$ & \multirow{2}{*}{0.245} \\
\hline & $>50 \mathrm{~mm}$ & $12(63.2)$ & $7(36.8)$ & \\
\hline \multirow{2}{*}{$\begin{array}{l}\text { NACT } \\
\text { combination }\end{array}$} & $\mathrm{CF}$ & $27(75)$ & $9(25)$ & \multirow{2}{*}{0.335} \\
\hline & Others ${ }^{2}$ & $4(57.1)$ & $3(42.9)$ & \\
\hline \multirow{2}{*}{$\begin{array}{l}\text { Number of NACT } \\
\text { cycles }\end{array}$} & 2 & $14(87.5)$ & $2(12.5)$ & \multirow{2}{*}{0.083} \\
\hline & 3 & $17(63)$ & $10(37)$ & \\
\hline \multirow{2}{*}{$\begin{array}{l}\text { Histopathologic } \\
\text { type }\end{array}$} & $\begin{array}{l}\text { Squamous } \\
\text { cell }\end{array}$ & $28(71.8)$ & $11(28.2)$ & \multirow[t]{2}{*}{0.892} \\
\hline & Others $^{3}$ & $3(75)$ & $1(25)$ & \\
\hline \multicolumn{5}{|c|}{$\begin{array}{l}{ }^{1} \text { Median value, }{ }^{2} \text { Carboplatin and paclitaxel, cisplatin and UFT }{ }^{\mathrm{TM}} \text {, } \\
\text { 'Adenocancer+adenosquamous cell cancer, CCR: Complete clinical response, PCR: } \\
\text { Partial clinical response, SD: Stabile disease, PD: Progressive disease, NACT: Neoadjuvant } \\
\text { chemotherapy, CF: Cisplatin and 5-fluorouracil, FIGO: Federation of Gynecology and } \\
\text { Obstetrics }\end{array}$} \\
\hline
\end{tabular}

stage CC. After NACT, these studies have reported that the CCR rates ranged from 0\% to 50\%, whereas CCR + PCR rates ranged from $45 \%$ to $95 \%{ }^{(12,15-46)}$. In the survival analysis, the 5-year OS and DFS rates varied between 28\% and $92.1 \%$ and from $29 \%$ to $85 \%$, respectively ${ }^{(12,15,19,20,24-26,28,30,34,35,39-42,44-52)}$. The results of the present study were analyzed in the light of these literature data.

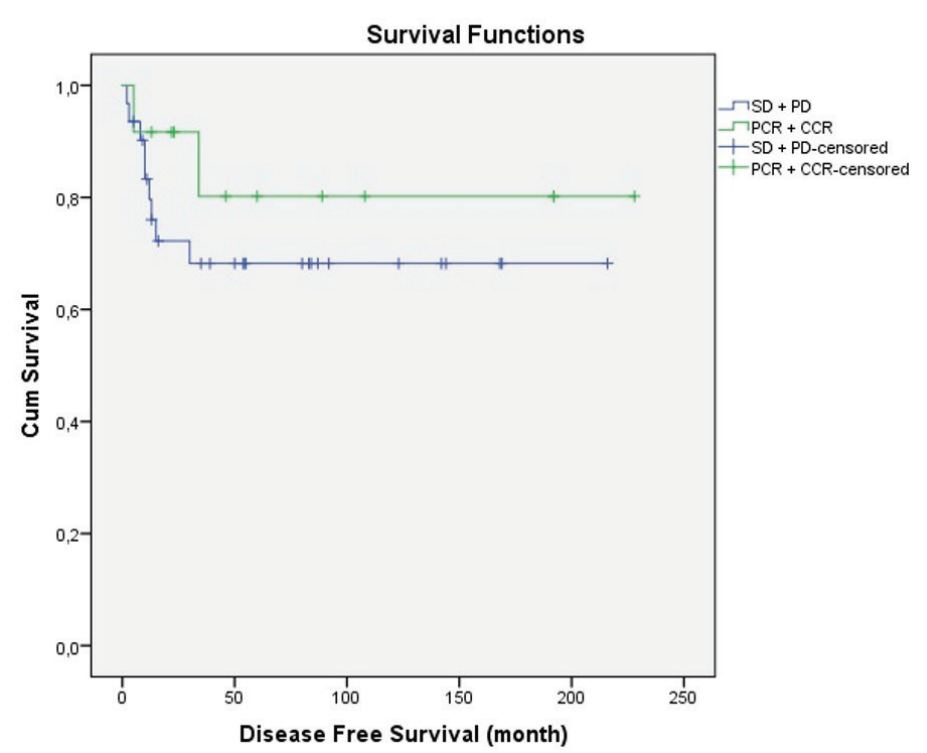

Figure 1. Disease-free survival and clinical response

CCR: Complete clinical response, PCR: Partial clinical response, $\mathrm{SD}$ : Stable disease, PD: Progressive disease

\section{Discussion}

NACT is the standard treatment in especially breast and headneck cancers and in many other solid tumors. Despite years of experience, the value of NACT in the treatment of CC is still undetermined.

In theory, NACT is expected to increase the operability by decreasing the tumor size and to improve the surgical prognostic factors by destroying micrometastasis. CT given before the RH and RT, which damage the circulation of the tissues, is thought 
Table 4. Effects of clinical and pathological parameters on diseasefree survival

\begin{tabular}{|c|c|c|c|}
\hline \multicolumn{2}{|c|}{ Clinical and pathological parameters } & $\begin{array}{l}\text { 5-year } \\
\text { disease-free } \\
\text { survival (\%) }\end{array}$ & $\mathbf{p}$ \\
\hline \multirow{2}{*}{$\mathrm{Age}^{1}$} & $\leq 48$ years & 86 & \multirow{2}{*}{0.141} \\
\hline & $>48$ years & 61 & \\
\hline \multirow{2}{*}{ FIGO 2009 stage } & I & 73 & \multirow{2}{*}{0.710} \\
\hline & II & 72 & \\
\hline \multirow[t]{2}{*}{ Histopathologic type } & $\begin{array}{l}\text { Squamous cell } \\
\text { cancer }\end{array}$ & 72 & \multirow[t]{2}{*}{0.866} \\
\hline & Others2 & 67 & \\
\hline \multirow[t]{2}{*}{ NACT protocol } & $\begin{array}{l}\text { Cisplatin and } \\
\text { 5-fluorouracil }\end{array}$ & 76 & \multirow[t]{2}{*}{0.233} \\
\hline & Others3 & 57 & \\
\hline \multirow{2}{*}{$\begin{array}{l}\text { Treatment after } \\
\text { NACT }\end{array}$} & Surgery & 72 & \multirow{2}{*}{0.841} \\
\hline & Radiotherapy & 74 & \\
\hline \multirow{5}{*}{$\begin{array}{l}\text { Rate of decrease } \\
\text { in tumor size after } \\
\text { NACT }\end{array}$} & Did not decreased & 86 & \multirow{5}{*}{0.304} \\
\hline & $<25 \%$ & 50 & \\
\hline & $\geq 25 \%,<50 \%$ & 70 & \\
\hline & $\begin{array}{l}\geq 50 \% \text { (with gross } \\
\text { tumor) }\end{array}$ & 73 & \\
\hline & $\begin{array}{l}\text { No gross tumor } \\
\text { (clinically) }\end{array}$ & 100 & \\
\hline \multirow{2}{*}{ Clinical response } & $\mathrm{SD}+\mathrm{PD}$ & 68 & \multirow{2}{*}{0.374} \\
\hline & $\mathrm{CCR}+\mathrm{PCR}$ & 80 & \\
\hline \multirow{2}{*}{ Number of courses } & 2 & 67 & \multirow{2}{*}{0.530} \\
\hline & 3 & 74 & \\
\hline \multirow{2}{*}{$\begin{array}{l}\text { Tumor size before } \\
\text { NACT }(\mathrm{mm})^{1}\end{array}$} & $\leq 50$ & 77 & \multirow{2}{*}{0.396} \\
\hline & $>50$ & 66 & \\
\hline \multirow{2}{*}{$\begin{array}{l}\text { Tumor size after } \\
\text { NACT }(\mathrm{mm})^{1}\end{array}$} & $\leq 30$ & 78 & \multirow{2}{*}{0.238} \\
\hline & $>30$ & 64 & \\
\hline \multirow{2}{*}{$\begin{array}{l}\text { Lymph node } \\
\text { metastasis }^{4}\end{array}$} & Negative & 67 & \multirow{2}{*}{0.326} \\
\hline & Positive & 81 & \\
\hline
\end{tabular}

${ }^{1}$ Median value, ${ }^{2}$ Adenocancer+adenosquamous cell cancer, ${ }^{3} \mathrm{Carboplatin} /$ paclitaxel, cisplatin/UFT ${ }^{\mathrm{TM}}$

${ }^{4}$ Lymph node metastasis evaluated in 38 patients (31 patients underwent radical hysterectomy+lymphadenectomy and seven patients underwent extraperitoneal/ transperitoneal lymphadenectomy+radiotherapy), NACT: Neoadjuvant chemotherapy, SD: Stable disease, PD: Progressive disease, CCR: Complete clinical response, PCR: Partial clinical response, FIGO: Federation of Gynecology and Obstetrics

to be having more robust antitumoral effects.

Some of the studies have supported this theoretical approach. These studies, which were generally phase II studies, have shown that NACT improved surgical prognostic factors ${ }^{(19,47,49,53)}$. However, recent reports that compare the NACT followed by RH and RH alone do not show this improvement ${ }^{(12,19,40,46-49,54)}$.
Studies have reported that CCR obtained by NACT ranged from $0 \%$ to $50 \%$ (OCR, 25-95\%) (Table 5). After NACT, $28-100 \%$ of the patients became eligible for surgery ${ }^{(16-21,28,29,31,33,40,42,46,48,49,55)}$. One of the reasons of the variability of these rates is the nonhomogeneity of the stages analyzed in the studies. In most of these studies, patients had locally advanced CC ranging from stage IB2 to IVA. However, the response after NACT is directly correlated to the disease stage. In a meta-analysis, Eddy et al. ${ }^{(15)}$ reported that the CCR of $28 \%$ in stage IB2-IIA decreases to $7 \%$ in stage IV. Similar results were reported in other studies ${ }^{(23,25,30,43,50)}$.

The operability rates change parallel to the clinical response, and stage is also a determining factor. Dueñas-Gonzales et al. ${ }^{(30)}$ showed that operability is $83 \%$ in stage IB2, $60 \%$ in stage IIB, and $40 \%$ in stage IIIB. Gadduci et al. ${ }^{(43)}$ also reported that operability decreases in the advanced stage. These studies have revealed that NACT is inappropriate for CC in advanced stage because of the high probability of RT need, which should be limited to early disease stages.

In the study by Li et al. ${ }^{(46)}$, the DFS [hazard ratio (HR) 0.4, 95\% confidence interval (CI) 0.1-08\%; $\mathrm{p}=0.027$ ] and OS (HR: 0.1, 95\% CI: 0.01-0.8; $\mathrm{p}=0.026)$ rates were better in complete clinical responders than in non-responders. In the present study, the 5-year DFS rate was $80 \%$ in responders and $68 \%$ in non-responders. Similar results are demonstrated in other studies $^{(8,56)}$. By contrast, Pat CR determines the survival, which varied from $0 \%$ to $26 \%^{(12,16,17,19,20,23,25,34,36,46,55)}$.

Similar to response and operability, reported survival rates are varied (Table 6). The 5-year DFS and OS rates varied between 29\% and $85 \%$ and $28 \%$ and $92.1 \%$, respectively $(12,19,25,40,42,46,48,51,52)$. Our results are within this wide range (5-year DFS, 72\%; 5-year OS, 87\%). Lymph node metastasis, disease stage, parametrial involvement, stromal invasion, surgical border positivity, lymphovascular space invasion, histologic type, Pat $\mathrm{CR}$, and tumor size before and after treatment carry prognostic significance for survival. An et al. ${ }^{(57)}$ reported that deep stromal invasion, lymph node metastasis, and tumor size after NACT affect the OS rate $(p<0.05)$. The authors also showed that stromal invasion was an independent risk factor of DFS rate $(\mathrm{p}<0.05)$, and the OS rate was significantly affected by tumor size $>3 \mathrm{~cm}$ after NACT in a multivariate analysis. In the present study, none of risk factors were significant in the survival analysis.

Understanding the place of the NACT is difficult owing to the variability of the reported results. The non-homogeneity of the study group in terms of stages is one of the reasons of the variability. Survival after NACT is lower in advanced stages $^{(25,58-60)}$, and NACT has not any contribution to survival in these stages ${ }^{(30)}$. Results of the studies in which study group consisted of patients with only stage IB2 disease were very variable (Table 6) ${ }^{(12,15,19)}$. One of the reasons is the uncertainty of the clinical staging. 
Table 5. Clinical response rates after NACT reported in studies

\begin{tabular}{|c|c|c|c|c|c|c|c|}
\hline Author & Stage & $\begin{array}{l}\text { Neoadjuvant chemotherapy } \\
\text { protocol }\end{array}$ & $\begin{array}{l}\text { Interval } \\
\text { (day) }\end{array}$ & $\begin{array}{l}\text { CCR } \\
(\%)\end{array}$ & $\begin{array}{l}\text { PCR } \\
(\%)\end{array}$ & $\begin{array}{l}\text { SD } \\
(\%)\end{array}$ & $\begin{array}{l}\text { PD } \\
(\%)\end{array}$ \\
\hline Eddy et al., 1995(15) & IB2 & Cis+vinc, 3 cycles & $10 \mathrm{~d}$ & 6 & 76 & 15 & 3 \\
\hline Giardina et al., $1997^{(17)}$ & IB2-IIIB & Cis, 4 doses & $7 \mathrm{~d}$ & 28 & 57 & 15 & \\
\hline Fujiwaki et al., 1997(18) & IIB & Cis+peplo or doxo, 1 cycle & - & 4 & 75 & 21 & \\
\hline Zanetta et al., 1998(20) & IB2-IVA & Cis+ifos+pacli, 3 cycles & $21 \mathrm{~d}$ & 28.9 & 55.3 & 13.2 & 2.6 \\
\hline Sugiyama et al., 1999(21) & IIIB & Cis or carb+peplo, 2 cycles & $21 \mathrm{~d}$ & 7.1 & 60.7 & 32.1 & 0 \\
\hline Etcheverry et al., 2000 (25) & IB2-IIIB & Cis+ifos+5-FU, 3 cycles & $21 \mathrm{~d}$ & 30 & 55 & 10.6 & 4.4 \\
\hline Hwang et al., 2001 (26) & IB2-IIB & Cis+vinc+bleo, 3 cycles & $21 \mathrm{~d}$ & 50 & 43.7 & 6.3 & 0 \\
\hline Aoki et al., $2001^{(27)}$ & IB2-IIB & Cis+vinc+peplo, 2 cycles & $21 \mathrm{~d}$ & 0 & 86 & 14 & 0 \\
\hline Aoki et al., $2001^{(28)}$ & IB-III & $\mathrm{Cis}(\mathrm{IA})+5-\mathrm{FU}(\mathrm{IA}), 2$ or 3 cycles & $21 \mathrm{~d}$ & 0 & 64 & 27 & 9 \\
\hline Porzio et al., 2001 ${ }^{(29)}$ & IB2-IIB & Cis+vinc+bleo, 3 doses & $7 \mathrm{~d}$ & 70 & & 30 & 0 \\
\hline Dueños-Gonzales et al., $2001^{(30)}$ & IB2-IIIB & Cis+gemci, 3 cycles & $21 \mathrm{~d}$ & 7.5 & 87.5 & 5 & \\
\hline D'Agostino et al., 2002 & IB2-IVA & Cis+pacli+epir, 2 or 3 cycles & $21 \mathrm{~d}$ & 19 & 59.5 & 12 & 9.5 \\
\hline Fuso et al., $2005^{(37)}$ & IB2-IIB & Cis-based CT* 3 cycles & $21 \mathrm{~d}$ & 24.7 & 39.7 & 35.6 & \\
\hline Choi et al., 2006(38) & IB1-IIA & Cis $+5-\mathrm{FU}, 2$ or 3 cycles & $21 \mathrm{~d}$ & 16 & 50 & 34 & 0 \\
\hline Eddy et al., 2007 $7^{(12)}$ & IB2 & Cis+vinc, 3 cycles & $10 \mathrm{~d}$ & 15 & 37 & 45.5 & 2.3 \\
\hline Gong et al., 2012(39) & IB2-IIB & Cis-based protocols, 1 or 3 cycles & Change* & 4 & 86 & 10 & \\
\hline Katsumata et al., 2013(40) & IB2-IIB & Cis+mit+bleo, 2 or 4 cycles & $21 d$ & 66 & & 34 & \\
\hline Angioli et al., $2015^{(41)}$ & IB2-IIB & Cis+pacli, 3 cycles & $21 \mathrm{~d}$ & 84.6 & & 15.3 & \\
\hline Lee et al., $2016^{(42)}$ & IB-IIB & Cis-based protocols ( 1 or 8 cycles) & Change* & 84.6 & & 15.3 & \\
\hline Gadducci et al., 2017 $7^{(43)}$ & IB-IVA & Cis+pacli, 6 cycles & $7 \mathrm{~d}$ & 35.2 & 47.1 & 17.7 & 0 \\
\hline Gadducci et al., 2018 ${ }^{(44)}$ & IB2-IIB & Cis-based protocols, 3 or 6 cycles & Change* & 11 & 70.7 & 18.3 & \\
\hline Mori et al., 2019(45) & IB2-IIB & Irinotecan+nedaplatin, 2 cycles & $21 d$ & 62.5 & & 9.4 & \\
\hline Li et al., $2019^{(46)}$ & IB2-IIB & Cis-based protocols & Change* & 9 & 57 & 37 & \\
\hline Our study & IB2, IIA2, IIB & Cis-based protocols, 2 or 3 cycles & Change* & 9.3 & 18.6 & 69.9 & 2.3 \\
\hline
\end{tabular}

* Interval changes according to protocols, CCR: Complete clinical response, PCR: Partial clinical response, SD: Stable disease, PR: Progressive disease, Cis: Cisplatinum, Vinc: Vincristine, Peplo: Peplomycin, Doxo: Doxorubicin: Ifos: Ifosfamide, Bleo: Bleomycin, Pacli: Paclitaxel, MTX: Methotrexate, 5-FU: 5-fluorouracil, Gemci: Gemcitabine, Epir: Epirubicin, Mit: Mitomisin, IA: Intra-arterial infusion 
Table 6 . Survivals rates obtained by neoadjuvant chemotherapy

\begin{tabular}{|c|c|c|c|c|c|c|}
\hline Author & Stage & $\begin{array}{l}\text { Neoadjuvant chemotherapy } \\
\text { protocol }\end{array}$ & $\begin{array}{l}\text { Interval } \\
\text { (day) }\end{array}$ & Time for survival & $\begin{array}{l}\text { DFS } \\
(\%)\end{array}$ & $\begin{array}{l}\text { OS } \\
(\%)\end{array}$ \\
\hline Eddy et al., $1995^{(15)}$ & IB2 & Cis+vinc, 3 cycles & $10 \mathrm{~d}$ & 2 years & 85 & 88 \\
\hline Kim et al., 1989 & IB2-IIIB & Cis+vinb+bleo, 3 cycles & $21 \mathrm{~d}$ & 2 years & 94 & 94 \\
\hline \multirow{2}{*}{ Behtash et al., 2006 ${ }^{(48)}$} & \multirow{2}{*}{ IB2-IIA } & \multirow{2}{*}{ Cis+vinc, 3 cycles } & \multirow{2}{*}{$10 \mathrm{~d}$} & 3 years & 44 & 56 \\
\hline & & & & 5 Years & 29 & 28 \\
\hline \multirow{2}{*}{ Eddy et al., 2007(12) } & \multirow{2}{*}{ IB2 } & \multirow{2}{*}{ Cis+vinc, 3 cycles } & \multirow{2}{*}{10} & 3 years & 59.7 & NR \\
\hline & & & & 5 years & 56.2 & NR \\
\hline Etcheverry et al., 2000(25) & IB2-IIIB & Cis+ifos+5-FU, 3 cycles & $21 \mathrm{~d}$ & 5 years & 78 & 78 \\
\hline \multirow{2}{*}{ Serur et al., $1997^{(19)}$} & \multirow{2}{*}{ IB2 } & Cis+MTX+bleo, 3 cycles & $21 \mathrm{~d}$ & \multirow{2}{*}{5 years } & \multirow{2}{*}{80} & \multirow{2}{*}{80} \\
\hline & & Cis+vinc+bleo, 3 cycles & $10 \mathrm{~d}$ & & & \\
\hline Sardi et al., $1997^{(49)}$ & IB1-IB2 & Cis+vinc+bleo, 3 cycles & $10 \mathrm{~d}$ & 7 years & 88 & 82 \\
\hline Hwang et al., 2001 ${ }^{(26)}$ & IB2-IIB & Cis+vinc+bleo, 3 cycles & $21 \mathrm{~d}$ & 10 years & 80 & 97.5 \\
\hline Zanetta et al., $1998^{(20)}$ & IB2-IVA & Cis+ifos+pacli, 3 cycles & $21 \mathrm{~d}$ & Median f-u:16 months & 76 & 94 \\
\hline Duenas-Gonzales et al., $2003^{(34)}$ & IB2-IIIB & Carb+pacli, 3 cycles & $21 \mathrm{~d}$ & Median f-u:21 months & 79 & 79 \\
\hline Duenas-Gonzales et al., $2001^{(30)}$ & IB2-IIIB & Cis+gemci, 3 cycles & $21 \mathrm{~d}$ & Median f-u:28 months & 55 & 62 \\
\hline Aoki et al., $2001^{(28)}$ & IB-III & Cis +5-FU (IA), 2 or 3 cycles & $21 \mathrm{~d}$ & Median f-u:30 months & 18.2 & 27.3 \\
\hline Chang et al., 2000 24$)$ & IB2-IIA & Cis+vinc+bleo, 3 cycles & $10 \mathrm{~d}$ & Median f-u:39 months & 69 & 79 \\
\hline \multirow{2}{*}{ Buda et al., 2005(50) } & \multirow{2}{*}{ IB2-IVA } & Cis+ifos+pacli, 3 cycles & \multirow{2}{*}{$21 \mathrm{~d}$} & \multirow{2}{*}{ Median f-u:43 months } & 74 & 75 \\
\hline & & Cis+ifos, 3 cycles & & & 70 & 63 \\
\hline Huang et al., $2003^{(35)}$ & IB2-IIA & Cis+vinc+bleo, 3 cycles & $10 \mathrm{~d}$ & Median f-u:49 months & 65 & 69 \\
\hline Yin et al., $2011^{(51)}$ & IB2-IIB & Cis-based protocols, 2 or 3 cycles & Change* & 5 years & 85 & 88.7 \\
\hline Gong et al., 2012 (39) & IB2-IIB & Cis-based protocols, 1 or 3 cycles & Change* $^{*}$ & 2 years & 93 & 95.5 \\
\hline Katsumata et al., 2013 $3^{(40)}$ & IB2-IIB & Cis+mit+bleo, 2 or 4 cyles & $21 \mathrm{~d}$ & 5 years & 59.9 & 70 \\
\hline Angioli et al., $2015^{(41)}$ & IB2-IIB & Cis+pacli, 3 cycles & $21 \mathrm{~d}$ & 4 years & 80 & 84 \\
\hline Lee et al., $2016^{(42)}$ & IB-IIB & Cis-based protocols ( 1 or 8 cycles) & Change* & 5 years & 75.6 & 92.1 \\
\hline Gupta et al., 2018 (52) & IB2-IIB & Cis+pacli, 3 cycles & $21 \mathrm{~d}$ & 5 years & 69.3 & 75.4 \\
\hline Gadducci et al., 2018 $8^{(44)}$ & IB2-IIB & Cis-based protocols, 3 or 6 cycles & Change* & Median f-u:89 months & 72 & 77 \\
\hline Mori et al., 2019(45) & IB2-IIB & Irinotecan+nedaplatin, 2 cycles & $21 \mathrm{~d}$ & 5 years & 78.8 & 89.7 \\
\hline Li et al., $2019^{(46)}$ & IB2-IIB & Cis-based protocols & Change* $^{*}$ & 5 years & 70 & 75 \\
\hline Our study & $\begin{array}{l}\text { IB2, IIA2, } \\
\text { IIB }\end{array}$ & Cis-based protocols, 2 or 3 cycles & Change* & 5 years & 72 & 87 \\
\hline
\end{tabular}

*Interval changes according to protocols, DFS: Disease-free survival, OS: Overall survival, NR: Not reported, median f-u, median follow-up, Cis: Cisplatinum, Vinc: Vincristine, Vinb: Vinblastine, Ifos: Ifosfamide, Bleo: Bleomycin, Pacli: Paclitaxel, MTX: Methotrexate, 5-FU: 5-fluorouracil, Gemci: Gemcitabine, IA: Intra-arterial

The diversity of the CT protocols may be another reason for the variability of the results. CT protocols do not affect response and survival because many of them are cisplatin-based ${ }^{(55)}$. A multicenter randomized phase III trial in Italy comparing cisplatin/ifosfamide/paclitaxel combination with cisplatin/ ifosfamide showed that triple NACT protocol improved the CCR significantly (20\% and 9\%) $)^{(50)}$. No difference was found between the two $\mathrm{C}$ protocols in terms of the operability and 198 survival. In a randomized controlled study by Yang et al. ${ }^{(61)}$, NACT combination irinotecan plus cisplatin (IP group) and paclitaxel plus cisplatin (TP group) were compared. The authors reported no difference between the two groups in terms of OS and DFS (OS, $\mathrm{p}=0.212$; DFS, $\mathrm{p}=0.296$ ).

Data related to the CF combination are generally derived from concurrent chemoradiotherapy. The reported Pat CR changed from $40 \%$ to $67.5 \%{ }^{(62-64)}$. However, there is a limited number of 
studies that have used this NACT. Choi et al. ${ }^{(38)}$ reported that the CCR was $16 \%$ in stage IB1-IIA, the 5 -year OS rate was $80.7 \%$, and the 10 -year OS was $77 \%$. Etcheverry et al. ${ }^{(25)}$ reported CCR and Pat CR of 30\% and 13\%, respectively (stage IB2-IIIB), in which ifosfamide was added to the CF combination. The 5-year OS was $78 \%$ in this study.

In a meta-analysis, Zhu et al. ${ }^{(65)}$ included 4727 patients, in which the patients had FIGO stage IB and IIB CC and NACT combination consisted of platinum and/or taxane-based CT. Their clinical response rate ranged from $58.49 \%$ to $86.54 \%$, and the pathological response rate ranged from $7.5 \%$ to $78.81 \%$. Moreover, Zhu et al. ${ }^{(65)}$ indicated that clinical and pathologic responses were associated with a favorable prognosis. Meng et al. ${ }^{(66)}$ compared NACT+RH with RH. As NACT combination, cisplatin plus paclitaxel were implemented. The clinical response rate (CCR+PR) was $80.5 \%$ in the $\mathrm{RH}$ group and $91.2 \%$ in the NACT+RH group ( $\mathrm{p}=0.048)$. In our study, which includes stage IB2-IIB, the CCR was $9.3 \%$, the Pat CR was $6.9 \%$, and the 5 -year OS rate was $87 \%$.

NACT for cervical cancer meta-analysis collaboration reevaluated the data of 21 phase III trials performed between 1975 and 2000 and reported them in a meta-analysis ${ }^{(11)}$. Results are divided into the two groups. Studies that compared NACT followed by RT (NACT+RT) and RT alone (16 studies, n=2.074) were included in the first group, and studies that compared NACT+RH and RH (5 studies, $n=872$ ) were included in the second group. After the assessment of the second group, NACT + RH decreased the mortality rate by $35 \%$ and improved the survival by $12 \%$ when compared with the RT group. Only two of the five studies in the second group included stage IB2 tumors ${ }^{(24,55)}$. Benedetti-Panici et al. ${ }^{(55)}$ defined the survival advantage by NACT in stage IB2 disease in the subgroup analysis, but Chang et al. ${ }^{(24)}$ did not show any advantage. In addition, Chang et al. ${ }^{(24)}$ showed that clinical response was higher in the RT group, but Sardi et al. ${ }^{(49)}$ showed that the clinical response was better in the NACT group than in NACT+RH+adjuvant RT and RH+adjuvant RT groups. Recently, Zou et al. ${ }^{(67)}$ published a meta-analysis involving 2.270 patients with stage IB2-IIB CC and evaluating the efficacy of concurrent chemoradiation and NACT followed by radical surgery $(\mathrm{NACT}+\mathrm{RH})$. They stated that compared with the concurrent chemoradiation group, the NACT+RH group did not have a survival advantage (OS, $\mathrm{p}=0.07$; DFS, $\mathrm{p}=0.82)^{(67)}$. Patients receiving NACT with concurrent chemoradiation were compared in another randomized phase II study, and authors revealed that prognosis in the concurrent chemoradiation group was more favorable than that in the NACT group (DFS, HR 1.84, 95\% CI 1.04-3.26, p=0.033; OS, HR 2.79, 95\% CI 1.29-6.01, $\mathrm{p}=0.006)^{(68)}$. European Organisation for Research and Treatment of Cancer (ClinicalTrials.gov identifier: NCT00039338) investigated the effect of NACT+RH against concurrent chemoradiation in patients with stage IB2-IIB disease using cisplatin-based CT regimens. Unfortunately, some of its data are still not yet published. The results of this study will shed light on the management of these patient groups. Aoki et al. ${ }^{(27)}$ compared NACT+RH and RH alone (stage IBIIB) and reported that the pathological prognostic factors and survival were better in the NACT group. Similar results were also reported by Namkoong et al. ${ }^{(69)}$ (stage IB-IIB). By contrast, in their randomized controlled trial, Yang et al. ${ }^{(61)}$ showed that pathologic prognostic factors were improving in the NACT group, but it does not affect the survival. Yang et al. ${ }^{(54)}$ found similar survival results between the NACT+RH and RH groups in their meta-analysis of 16 studies. A retrospective study ${ }^{(4)}$ compared NACT+RH and RH alone in early-stage CC, and a prospective phase III study by GOG ${ }^{(12)}$ was published. These studies concluded that NACT has no place in the treatment of early-stage CC. In the study of GOG, surgical prognostic factors and survival in stage IB2 tumors were not improved by NACT (cisplatin/vincristine, every 10 days, three courses). The 5 -year OS was $56.2 \%$ in the NACT group and $53.8 \%$ in the RH group $^{(12)}$.

An article compared the effectiveness of NACT or primary RH in patients with stage 1B2 CC previously treated in our clinic ${ }^{(70)}$. In this study, 24 patients who received NACT followed by radical surgery were compared with 15 patients who underwent primary radical surgery. Patients were divided into three groups, including RH alone, NACT unresponder group, and NACT responder group. No difference was found between these groups in terms of recurrence, DFS, and OS.

\section{Study Limitations}

The retrospective design is the most critical limitation of the present study. Moreover, improvements in surgical and adjuvant therapy modalities over years may affect the results. In addition, the small sample size and the fact that NACT was not compared with other treatment methods (RH, CCRT, etc.) also limited the interpretation of the results. As strengths, detailed clinical-pathological characteristics and adjuvant treatments of the patients were evaluated. Pathologic examinations were performed by experienced gynecological pathologists. Followup periods of the patients were long. Additionally, the results were revised in the light of various relevant studies published in the literature.

\section{Conclusion}

The value of NACT in the treatment of CC is still being debated and discussed. At present, it is thought that NACT may be used in locally advanced CC, but results reveal that this is not feasible. By contrast, we think that new drugs, new combinations, and new protocols of NACT could achieve successful treatment of $\mathrm{CC}$, as in theory.

\section{Ethics}

Ethics Committee Approval: This study was approved by the Etlik Zübeyde Hanım Women's Health Training and Research Hospital Ethical Committee (file no. 90057706-799/08; 05.06.2020). 
Informed Consent: Medical records of patients with stage IB2, IIA2, or IIB CC between 1998 and 2020 were reviewed retrospectively.

Peer-review: Externally peer-reviewed.

\section{Authorship Contributions}

Surgical and Medical Practices: C.Ç., F.K., R.D., D.Y., M.Ü., V.K., C..K., G.K.C., N.B., O.T., S.K., T.T., Concept: C.C.., F.K., R.D., D.Y., M.Ü., V.K., C..K., G.K.C., N.B., O.T., S.K., T.T., Design: C.Ç., F.K., R.D., D.Y., M.Ü., V.K., C..K., G.K.C., N.B., O.T., S.K., T.T., Data Collection or Processing: C.Ç., F.K., R.D., D.Y., M.Ü., V.K., Ç.K., G.K.C., N.B., O.T., S.K., T.T., Analysis or Interpretation: C.Ç., F.K., R.D., D.Y., M.Ü., V.K., Ç.K., G.K.C., N.B., O.T., S.K., T.T., Literature Search: C.Ç., F.K., R.D., D.Y., M.Ü., V.K., Ç.K., G.K.C., N.B., O.T., S.K., T.T., Writing: C.Ç., R.D., V.K., O.T., T.T.

Conflict of Interest: The authors report no conflict of interest. Financial Disclosure: Authors have no financial interests about the research.

\section{References}

1. Bray F, Ferlay J, Soerjomataram I, Siegel RL, Torre LA, Jemal A. Global cancer statistics 2018: GLOBOCAN estimates of incidence and mortality worldwide for 36 cancers in 185 countries. CA Cancer J Clin 2018;68:394-424.

2. Koh WJ, Abu-Rustum NR, Bean S, Bradley K, Campos SM, Cho KR, et al. Cervical Cancer, Version 3.2019, NCCN Clinical Practice Guidelines in Oncology. J Natl Compr Canc Netw 2019;17:64-84.

3. Cohen PA, Jhingran A, Oaknin A, Denny L. Cervical cancer. Lancet 2019;393:169-82.

4. Landoni F, Maneo A, Colombo A, Placa F, Milani R, Perego P, et al. Randomised study of radical surgery versus radiotherapy for stage Ib-Ila cervical cancer. Lancet 1997;350:535-40.

5. Peters WA $3^{\text {rd }}$, Liu PY, Barrett RJ $2^{\text {nd }}$, Stock RJ, Monk BJ, Berek JS, et al. Concurrent chemotherapy and pelvic radiation therapy compared with pelvic radiation therapy alone as adjuvant therapy after radical surgery in high-risk early-stage cancer of the cervix. J Clin Oncol 2000;18:1606-13.

6. Tattersall MH, Ramirez C, Coppleson M. A randomized trial comparing platinum-based chemotherapy followed by radiotherapy vs. radiotherapy alone in patients with locally advanced cervical cancer. Int J Gynecol Cancer 1992;2:244-51.

7. Herod J, Burton A, Buxton J, Tobias J, Luesley D, Jordan S, et al. A randomised, prospective, phase III clinical trial of primary bleomycin, ifosfamide and cisplatin (BIP) chemotherapy followed by radiotherapy versus radiotherapy alone in inoperable cancer of the cervix. Ann Oncol 2000;11:1175-81.

8. Tattersall MH, Lorvidhaya V, Vootiprux V, Cheirsilpa A, Wong F, Azhar T, et al. Randomized trial of epirubicin and cisplatin chemotherapy followed by pelvic radiation in locally advanced cervical cancer. Cervical Cancer Study Group of the Asian Oceanian Clinical Oncology Association. J Clin Oncol 1995;13:444-51.

9. Kumar L, Kaushal R, Nandy M, Biswal BM, Kumar S, Kriplani A, et al. Chemotherapy followed by radiotherapy versus radiotherapy alone in locally advanced cervical cancer: a randomized study. Gynecol Oncol 1994;54:307-15.

10. Edelmann DZ, Anteby SO. Neoadjuvant chemotherapy for locally advanced cervical cancer--where does it stand?: a review. Obstet Gynecol Surv 1996;51:305-13.
11. Neoadjuvant Chemotherapy for Locally Advanced Cervical Cancer Meta-analysis Collaboration. Neoadjuvant chemotherapy for locally advanced cervical cancer: a systematic review and meta-analysis of individual patient data from 21 randomised trials. Eur J Cancer 2003;39:2470-86.

12. Eddy GL, Bundy BN, Creasman WT, Spirtos NM, Mannel RS, Hannigan E, et al. Treatment of ("bulky") stage IB cervical cancer with or without neoadjuvant vincristine and cisplatin prior to radical hysterectomy and pelvic/para-aortic lymphadenectomy: a phase III trial of the gynecologic oncology group. Gynecol Oncol 2007;106:362-9.

13. Carcangiu M, Kurman RJ, Herington CS. WHO classification of tumours of female reproductive organs. 4th ed. Lyon, France:International Agency for Research on Cancer; 2014 p. 307.

14. WHO. WHO handbook for reporting results of cancer treatment. Geneva: World Health Organization;1979.

15. Eddy GL, Manetta A, Alvarez RD, Williams L, Creasman WT. Neoadjuvant chemotherapy with vincristine and cisplatin followed by radical hysterectomy and pelvic lymphadenectomy for FIGO stage IB bulky cervical cancer: a Gynecologic Oncology Group pilot study. Gynecol Oncol 1995;57:412-6.

16. Lacava JA, Leone BA, Machiavelli M, Romero AO, Perez JE, Elem YL, et al. Vinorelbine as neoadjuvant chemotherapy in advanced cervical carcinoma. J Clin Oncol 1997;15:604-9.

17. Giardina G, Richiardi G, Danese S, Ottone P, Ohlmeier U, Gargiulo T. Weekly cisplatin as neoadjuvant chemotherapy in locally advanced cervical cancer: a well-tolerated alternative. Eur J Gynaecol Oncol 1997;18:173-6.

18. Fujiwaki R, Iida K, Ohnishi Y, Watanabe Y, Ryuko K, Takahashi $\mathrm{K}$, et al. Intra-arterial neoadjuvant chemotherapy followed by radical surgery and radiotherapy for stage IIb cervical carcinoma. Anticancer Res 1997;17:3751-5.

19. Serur E, Mathews RP, Gates J, Levine P, Maiman M, Remy JC. Neoadjuvant chemotherapy in stage IB2 squamous cell carcinoma of the cervix. Gynecol Oncol 1997;65:348-56.

20. Zanetta G, Lissoni A, Pellegrino A, Sessa C, Colombo N, Gueli-Alletti D, et al. Neoadjuvant chemotherapy with cisplatin, ifosfamide and paclitaxel for locally advanced squamous-cell cervical cancer. Ann Oncol 1998;9:977-80.

21. Sugiyama T, Nishida T, Muraoka Y, Tokuda T, Kuromatsu H, Fujiyoshi K, et al. Radical surgery after neoadjuvant intra-arterial chemotherapy in stage IIIb squamous cell carcinoma of the cervix. Int Surg 1999;84:67-73.

22. Sugiyama T, Nishida T, Kumagai S, Nishio S, Fujiyoshi K, Okura $\mathrm{N}$, et al. Combination therapy with irinotecan and cisplatin as neoadjuvant chemotherapy in locally advanced cervical cancer. Br J Cancer 1999;81:95-8.

23. Pignata S, Silvestro G, Ferrari E, Selvaggi L, Perrone F, Maffeo A, et al. Phase II study of cisplatin and vinorelbine as first-line chemotherapy in patients with carcinoma of the uterine cervix. J Clin Oncol 1999;17:756-60.

24. Chang TC, Lai CH, Hong JH, Hsueh S, Huang KG, Chou HH, et al. Randomized trial of neoadjuvant cisplatin, vincristine, bleomycin, and radical hysterectomy versus radiation therapy for bulky stage IB and IIA cervical cancer. J Clin Oncol 2000;18:1740-7.

25. Etcheverry MG, Marantz A, Saine M, Litovska S, Lewi D, Cecchin $G$, et al. Neoadjuvant chemotherapy with cisplatin, ifosfamide and 5-fluorouracil in the treatment of locally advanced cervical cancer. Int J Gynecol Cancer 2000;10:53-8. 
26. Hwang YY, Moon H, Cho SH, Kim KT, Moon YJ, Kim SR, et al. Tenyear survival of patients with locally advanced, stage ib-iib cervical cancer after neoadjuvant chemotherapy and radical hysterectomy. Gynecol Oncol 2001;82:88-93.

27. Aoki Y, Tomita M, Sato T, Watanabe M, Kase H, Fujita K, et al. Neoadjuvant chemotherapy for patients younger than 50 years with high-risk squamous cell carcinoma of the cervix. Gynecol Oncol 2001;83:263-7.

28. Aoki Y, Sato T, Watanabe M, Sasaki M, Tsuneki I, Tanaka K. Neoadjuvant chemotherapy using low-dose consecutive intraarterial infusions of cisplatin combined with 5-fluorouracil for locally advanced cervical adenocarcinoma. Gynecol Oncol 2001;81:496-9.

29. Porzio G, Ficorella C, Toro G, Paris I, Ricevuto E, Marchetti P. Short-term weekly neoadjuvant chemotherapy in the treatment of locally advanced cervical cancer. Tumori 2001;87:25-6.

30. Dueñas-Gonzalez A, Lopez-Graniel C, Gonzalez A, Reyes M, Mota A, Muñoz D, et al. A phase II study of gemcitabine and cisplatin combination as induction chemotherapy for untreated locally advanced cervical carcinoma. Ann Oncol 2001;12:541-7.

31. D’Agostino G, Distefano M, Greggi S, Salerno M, Ferrandina G, Poerio A, et al. Neoadjuvant treatment of locally advanced carcinoma of the uterine cervix with epirubicin, paclitaxel and cisplatin. Cancer Chemother Pharmacol 2002;49:256-60.

32. Napolitano U, Imperato F, Mossa B, Framarino ML, Marziani R, Marzetti L. The role of neoadjuvant chemotherapy for squamous cell cervical cancer (Ib-IIIb): a long-term randomized trial. Eur J Gynaecol Oncol 2003;24:51-9.

33. Dueñas-González A, López-Graniel C, González A, Gomez E, Rivera L, Mohar A, et al. Induction chemotherapy with gemcitabine and oxaliplatin for locally advanced cervical carcinoma. Am J Clin Oncol 2003;26:22-5.

34. Dueñas-Gonzalez A, López-Graniel C, González-Enciso A, Cetina L, Rivera L, Mariscal I, et al. A phase II study of multimodality treatment for locally advanced cervical cancer: neoadjuvant carboplatin and paclitaxel followed by radical hysterectomy and adjuvant cisplatin chemoradiation. Ann Oncol 2003;14:1278-84.

35. Huang HJ, Chang TC, Hong JH, Tseng CJ, Chou HH, Huang KG, et al. Prognostic value of age and histologic type in neoadjuvant chemotherapy plus radical surgery for bulky $(>/=4 \mathrm{~cm})$ stage IB and IIA cervical carcinoma. Int J Gynecol Cancer 2003;13:204-11.

36. Termrungruanglert W, Tresukosol D, Vasuratna A, Sittisomwong T, Lertkhachonsuk R, Sirisabya N. Neoadjuvant gemcitabine and cisplatin followed by radical surgery in (bulky) squamous cell carcinoma of cervix stage IB2. Gynecol Oncol 2005;97:576-81.

37. Fuso L, Mazzola S, Marocco F, Ferrero A, Dompè D, Carus AP, et al. Pretreatment serum hemoglobin level as a predictive factor of response to neoadjuvant chemotherapy in patients with locally advanced squamous cervical carcinoma: a preliminary report. Gynecol Oncol 2005;99(3 Suppl 1):S187-91.

38. Choi YS, Sin JI, Kim JH, Ye GW, Shin IH, Lee TS. Survival benefits of neoadjuvant chemotherapy followed by radical surgery versus radiotherapy in locally advanced chemoresistant cervical cancer. J Korean Med Sci 2006;21:683-9.

39. Gong L, Lou JY, Wang P, Zhang JW, Liu H, Peng ZL. Clinical evaluation of neoadjuvant chemotherapy followed by radical surgery in the management of stage IB2-IIB cervical cancer. Int J Gynaecol Obstet 2012;117:23-6.

40. Katsumata N, Yoshikawa H, Kobayashi H, Saito T, Kuzuya K, Nakanishi T, et al; Japan Clinical Oncology Group. Phase III randomised controlled trial of neoadjuvant chemotherapy plus radical surgery vs radical surgery alone for stages IB2, IIA2, and IIB cervical cancer: a Japan Clinical Oncology Group trial (JCOG 0102). Br J Cancer 2013; 108:1957-63.

41. Angioli R, Plotti F, Aloisi A, Scaletta G, Capriglione S, Luvero D, et al. A randomized controlled trial comparing four versus six courses of adjuvant platinum-based chemotherapy in locally advanced cervical cancer patients previously treated with neo-adjuvant chemotherapy plus radical surgery. Gynecol Oncol 2015;139:433-8.

42. Lee J, Kim TH, Kim GE, Keum KC, Kim YB. Neoadjuvant chemotherapy followed by surgery has no therapeutic advantages over concurrent chemoradiotherapy in International Federation of Gynecology and Obstetrics stage IB-IIB cervical cancer. J Gynecol Oncol 2016;27:e52. doi: 10.3802/jgo.2016.27.e52.

43. Gadducci A, Barsotti C, Laliscia C, Cosio S, Fanucchi A, Tana R, et al. Dose-dense Paclitaxel- and Carboplatin-based Neoadjuvant Chemotherapy Followed by Surgery or Concurrent Chemoradiotherapy in Cervical Cancer: a Preliminary Analysis. Anticancer Res 2017;37:1249-55.

44. Gadducci A, Landoni F, Cosio S, Zizioli V, Zola P, Ferrero AM, et al. Neoadjuvant platinum-based chemotherapy followed by radical hysterectomy for stage ib2-iib adenocarcinoma of the uterine cervix - an italian multicenter retrospective study. Anticancer Res 2018;38:3627-34.

45. Mori T, Makino H, Okubo T, Fujiwara Y, Sawada M, Kuroboshi H, et al. Multi-institutional phase II study of neoadjuvant irinotecan and nedaplatin followed by radical hysterectomy and the adjuvant chemotherapy for locally advanced, bulky uterine cervical cancer: A Kansai Clinical Oncology Group study (KCOG-G1201). J Obstet Gynaecol Res 2019;45:671-8.

46. Li L, Wu M, Ma S, Tan X, Zhong S. Neoadjuvant chemotherapy followed by radical hysterectomy for stage IB2-to-IIB cervical cancer: a retrospective cohort study. Int J Clin Oncol 2019;24:1440-8.

47. Kim DS, Moon H, Kim KT, Hwang YY, Cho SH, Kim SR. Two-year survival: preoperative adjuvant chemotherapy in the treatment of cervical cancer stages Ib and II with bulky tumor. Gynecol Oncol 1989;33:225-30.

48. Behtash N, Nazari Z, Ayatollahi H, Modarres M, Ghaemmaghami F, Mousavi A. Neoadjuvant chemotherapy and radical surgery compared to radical surgery alone in bulky stage IB-IIA cervical cancer. Eur J Surg Oncol 2006;32:1226-30.

49. Sardi JE, Giaroli A, Sananes C, Ferreira M, Soderini A, Bermudez A, et al. Long-term follow-up of the first randomized trial using neoadjuvant chemotherapy in stage Ib squamous carcinoma of the cervix: the final results. Gynecol Oncol 1997;67:61-9.

50. Buda A, Fossati R, Colombo N, Fei F, Floriani I, Gueli Alletti D, et al. Randomized trial of neoadjuvant chemotherapy comparing paclitaxel, ifosfamide, and cisplatin with ifosfamide and cisplatin followed by radical surgery in patients with locally advanced squamous cell cervical carcinoma: the SNAPO1 (Studio NeoAdjuvante Portio) Italian Collaborative Study. J Clin Oncol 2005;23:4137-45.

51. Yin M, Zhao F, Lou G, Zhang H, Sun M, Li C, et al. The longterm efficacy of neoadjuvant chemotherapy followed by radical hysterectomy compared with radical surgery alone or concurrent chemoradiotherapy on locally advanced-stage cervical cancer. Int J Gynecol Cancer 2011;21:92-9.

52. Gupta S, Maheshwari A, Parab P, Mahantshetty U, Hawaldar R, Sastri Chopra S, et al. Neoadjuvant chemotherapy followed by radical surgery versus concomitant chemotherapy and radiotherapy 
in patients with stage IB2, IIA, or IIB squamous cervical cancer: a randomized controlled trial. J Clin Oncol 2018;36:1548-55.

53. Kim HS, Sardi JE, Katsumata N, Ryu HS, Nam JH, Chung HH, et al. Efficacy of neoadjuvant chemotherapy in patients with FIGO stage IB1 to IIA cervical cancer: an international collaborative metaanalysis. Eur J Surg Oncol 2013;39:115-24.

54. Yang SL, Chen L, He Y, Zhao H, Wu YM. Effect of neoadjuvant chemotherapy followed by surgery for FIGO stage I-II cervical cancer: a meta-analysis. J Int Med Res 2020;48:300060520945507. doi: 10.1177/0300060520945507.

55. Benedetti-Panici P, Greggi S, Colombo A, Amoroso M, Smaniotto D, Giannarelli D, et al. Neoadjuvant chemotherapy and radical surgery versus exclusive radiotherapy in locally advanced squamous cell cervical cancer: results from the Italian multicenter randomized study. J Clin Oncol 2002;20:179-88.

56. Souhami L, Gil RA, Allan SE, Canary PC, Araújo CM, Pinto LH, et al. A randomized trial of chemotherapy followed by pelvic radiation therapy in stage IIIB carcinoma of the cervix. J Clin Oncol 1991;9:970-7.

57. An JS, Zhao YX, Song Y, Li N, Huang MN, Li XG, et al. [Analysis of effects and postoperative clinicopathological prognosis factors of neoadjuvant chemotherapy in patients with stage Ib2 and Ia2 squamous cell carcinoma of the cervix]. Zhonghua $\mathrm{Fu}$ Chan $\mathrm{Ke} \mathrm{Za}$ Zhi 2019;54:673-9. (Chinese)

58. Benedetti-Panici P, Greggi S, Scambia G, Amoroso M, Salerno MG, Maneschi F, et al. Long-term survival following neoadjuvant chemotherapy and radical surgery in locally advanced cervical cancer. Eur J Cancer 1998;34:341-6.

59. Bloss JD, Lucci JA 3rd, DiSaia PJ, Manetta A, Schiano MA, Ramsinghani N, et al. A phase II trial of neoadjuvant chemotherapy prior to radical hysterectomy and/or radiation therapy in the management of advanced carcinoma of the uterine cervix. Gynecol Oncol 1995;59:105-10.

60. Sananes C, Giaroli A, Soderini A, Guardado N, Snaidas L, Bermudez A, et al. Neoadjuvant chemotherapy followed by radical hysterectomy and postoperative adjuvant chemotherapy in the treatment of carcinoma of the cervix uteri: long-term follow-up of a pilot study. Eur J Gynaecol Oncol 1998;19:368-73.

61. Yang Z, Chen D, Zhang J, Yao D, Gao K, Wang H, et al. The efficacy and safety of neoadjuvant chemotherapy in the treatment of locally advanced cervical cancer: A randomized multicenter study. Gynecol Oncol 2016;141:231-9.
62. Resbeut M, Cowen D, Viens P, Noirclerc M, Perez T, Gouvernet J, et al. Concomitant chemoradiation prior to surgery in the treatment of advanced cervical carcinoma. Gynecol Oncol 1994;54:68-75.

63. Jurado M, Martínez-Monge R, García-Foncillas J, Azinovic I, Aristu J, López-García G, et al. Pilot study of concurrent cisplatin, 5-fluorouracil, and external beam radiotherapy prior to radical surgery +/- intraoperative electron beam radiotherapy in locally advanced cervical cancer. Gynecol Oncol 1999;74:30-7.

64. Mancuso S, Smaniotto D, Benedetti Panici P, Favale B, Greggi S, Manfredi R, et al. Phase I-II trial of preoperative chemoradiation in locally advanced cervical carcinoma. Gynecol Oncol 2000;78:3248.

65. Zhu Y, Yang J, Zhang X, Chen D, Zhang S. Acquired treatment response from neoadjuvant chemotherapy predicts a favorable prognosis for local advanced cervical cancer: A metaanalysis. Medicine (Baltimore) 2018;97:e0530. doi: 10.1097/ MD.0000000000010530.

66. Meng X, Chu Y, Pan Y, Han L, Meng Z, Wang X. Preoperative neoadjuvant chemotherapy combined with radical surgery in cervical cancer. J BUON 2020;25:125-31.

67. Zou W, Han Y, Zhang Y, Hu C, Feng Y, Zhang H, et al. Neoadjuvant chemotherapy plus surgery versus concurrent chemoradiotherapy in stage IB2-IIB cervical cancer: A systematic review and metaanalysis. PLoS One 2019;14:e0225264. doi: 10.1371/journal. pone.0225264.

68. da Costa SCS, Bonadio RC, Gabrielli FCG, Aranha AS, Dias Genta MLN, Miranda VC, et al. Neoadjuvant chemotherapy with cisplatin and gemcitabine followed by chemoradiation versus chemoradiation for locally advanced cervical cancer: a randomized phase ii trial. J Clin Oncol 2019;37:3124-31.

69. Namkoong SE, Park JS, Kim JW, Bae SN, Han GT, Lee JM, et al. Comparative study of the patients with locally advanced stages I and II cervical cancer treated by radical surgery with and without preoperative adjuvant chemotherapy. Gynecol Oncol 1995;59:13642.

70. Turan T, Akdağ D, Boran N, Yüksel N, Tulunay G, Özgül N, et al. Is the initial treatment in stage IB2 cervical carcinoma neoadjuvant chemothreapy or primary surgery?. Gynecol Obstet Reprod Med 2009; 15:38-43. 